Abstract-The influences of age, size, and condition of spawning females on fecundity and oocyte quality were analyzed for the Patagonian stock of Argentine Hake (Merluccius hubbsi). Samples of mature females were collected in the spawning area as part of 2 research surveys conducted in January 2010 and 2011, during the peak of the reproductive season. Batch fecundity (BF) ranged between 40,500 (29 $\mathrm{cm}$ total length [TL]) and 2,550,000 (95 cm TL) hydrated oocytes, and was positively correlated with TL, gutted weight, age, hepatosomatic index (HSI), and the relative condition factor $(\mathrm{Kn})$. Relative fecundity ranged between 85 and 1040 hydrated oocytes $\mathrm{g}^{-1}$ and showed significant positive relationships with gutted weight, HSI, and $\mathrm{Kn}$; however, coefficients of determination were low for all regressions. Dry weights of samples of 100 hydrated oocytes ranged between 1.8 and $3.95 \mathrm{mg}$ and were positively correlated with all variables analyzed, including batch and relative fecundity. Multiple regression models created with data of the morphophysiological characteristics of females supported maternal influences on fecundity and egg weights. Within the studied size range $(29-95 \mathrm{~cm}$ TL), larger individuals had better somatic and egg condition, mainly revealed by higher HSI and hydrated oocytes with larger oil droplets

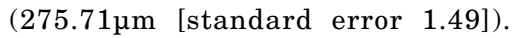
These results were associated with the higher feeding activity of larger females during the spawning season in comparison with the feeding activity of young individuals $(<5$ years old); the better nutritional state of larger females, assumed to result from more feeding, was conducive to greater production of high-quality eggs.

Manuscript submitted 11 January 2013. Manuscript accepted 7 August 2013. Fish. Bull. 111:325-336.

doi: 10.7755/FB.111.4.3

The views and opinions expressed or implied in this article are those of the author (or authors) and do not necesarily reflect the position of the National Marine Fisheries Service, NOAA.

\title{
Maternal effects on fecundity and egg quality of the Patagonian stock of Argentine Hake (Merluccius hubbsi)
}

\author{
Gustavo J. Macchi (contact author) 1, 2 \\ Ezequiel Leonarduzzi² \\ Marina V. Diaz² \\ Marta Renzi² \\ Karina Rodrigues ${ }^{1,2}$ \\ Email address for contact author: gmacchi@inidep.edu.ar \\ ${ }^{1}$ Consejo Nacional de Investigaciones Científicas y Técnicas (CONICET) \\ Av. Rivadavia 1917 \\ C1033AAJ Buenos Aires, Argentina \\ 2 Instituto Nacional de Investigación y Desarrollo Pesquero (INIDEP) \\ Paseo Victoria Ocampo Nro. 1 \\ B7602HSA Mar del Plata, Argentina
}

The Argentine Hake (Merluccius hubbsi), with a biomass of around 700,000 metric tons (t) estimated from virtual population analysis in 2009 , is one of the most important fish resources for the Argentine fleet (Irusta and Datri ${ }^{1}$; Villarino and Santos $^{2}$ ). Two main stocks have been identified in the Argentine Sea: the northern group (between $34^{\circ}$ and $41^{\circ} \mathrm{S}$ ) and the southern group (between $41^{\circ}$ and $\left.55^{\circ} \mathrm{S}\right)$. The latter group, known also as the Patagonian stock, is the most abundant population of this species, accounting for about $85 \%$ of the total biomass estimated for this

${ }^{1}$ Irusta, C. G., and L. D'Atri. 2010. Evaluación del estado del efectivo norte de $41^{\circ} \mathrm{S}$ de la merluza (Merluccius hubbsi) y estimación de la Captura Biológicamente Aceptable para el año 2011. INIDEP Informe Técnico Oficial No. 42, 28 p. [Available from INIDEP, Paseo Victoria Ocampo Nro. 1, B7602HSA Mar del Plata, Argentina.

2 Villarino, M. F., and B. Santos. 2010. Evaluación del estado de explotación del efectivo sur de $41^{\circ} \mathrm{S}$ de la merluza (Merluccius hubbsi) y estimación de las capturas biológicamente aceptables correspondiente al año 2011. INIDEP Informe Técnico Oficial No. 43, 27 p. [Available from INIDEP, Paseo Victoria Ocampo Nro. 1, B7602HSA Mar del Plata, Argentina.] fish resource in Argentina (Aubone et al., 2000). This fishery historically has registered the most important commercial landings for Argentina, with annual catches between 170,000 and $370,000 \mathrm{t}$ since 2000 (Sánchez et al., 2012). Nevertheless, during the 1990s, both stocks of Argentine Hake suffered overexploitation and their spawning biomass decreased drastically, and changes also were observed in the parent-stock structure (Aubone et al., 2000).

It has been shown that the reproductive potential of a fish stock is strongly influenced by the size and age of spawning females. During the reproductive season, older and larger individuals produce more oocytes than younger and smaller spawners because fecundity and spawning frequency are higher in larger females and, in general, their reproductive period is longer than the period of smaller spawners (Marshall et al., 1998; Marteinsdottir and Thorarinsson, 1998; Marteinsdottir and Begg, 2002; Macchi et al, 2004; Mehault et al., 2010). Therefore, variation in length composition of a fish stock caused by fishing activity or by other sources of mortality would affect the number of eggs spawned at 
a population level. In this sense, fecundity estimates by length class give information on the number of potential offspring that can be produced. Nevertheless, viability during the early life stages depends mainly on egg quality, which is associated with the quantity of nutrients stored in the oocytes (Brooks et al., 1997). Bromage et al. (1994) defined egg quality as "those characteristics of the egg that determine its capacity to survive." There are different methods and indices that can be used to estimate the quality of fish eggs. Some of them are very simple, such as those techniques where morphometrical attributes (e.g., egg diameter or weight and size of the oil droplet) are used, and others are more complex, such as those where the biochemical composition (e.g., lipid or protein concentration) of the oocytes are used (Nocillado et al., 2000).

Most studies have concluded that larger eggs are of better quality because they can produce larger larvae with higher survival rates (Hinckley, 1990; Rijnsdorp and Vingerhoed, 1994; Nissling et al., 1998; Trippel, 1998). It is a general assumption that larger larvae may have advantages in finding food and in actively swimming through the water column that increase their probability of survival (Brooks et al., 1997; Álvarez Colombo et al., 2011). In contrast, in some studies, no relationship between egg diameter and larval size was observed (Landaeta and Castro, 2012), or it was suggested that larger offspring could be more easily detected by predators, and, therefore, large larval size would increase the risk of mortality (Kjesbu et al., 1996). However, in general, it is assumed that increased egg size leads to higher larval survival.

Fish condition can be assessed through the use of different indices, on the basis of length:body-weight ratio (K) or liver-weight:body-weight ratio (hepatosomatic index [HSI]) or on the basis of the biochemical composition (e.g., lipids, proteins, or glycogen) of different tissues (Dominguez-Petit et al., 2010). It was observed that lipids play an important role as stored energy that can affect fecundity, oocyte quality, and larval viability (Wiegand, 1996; Lambert et al., 2003; Aristizabal, 2007). Therefore, because the liver is generally the organ with the highest levels of lipid storage for gadoids, the HSI may be considered a good descriptor of female condition, and a strong influence on reproduction (Marshall et al., 1999; Marteinsdottir and Begg, 2002; Alonso-Fernández, 2011).

Spawning of the Patagonian stock of the Argentine Hake occurs in waters off the province of Chubut in southern Argentina during spring and summer, and a main peak occurs between December and January (Macchi et al., 2007). This species is a batch spawner with indeterminate annual fecundity, meaning that unyolked oocytes continuously mature and are spawned throughout the reproductive season (Macchi et al., 2004). It has been reported that the size and age compositions of Argentine Hake females in Patagonian waters change during the spawning season, affecting egg production of this stock during this period (Macchi et al., 2004). Moreover, Macchi et al. (2006) found positive relationships between oocyte dry weight (DW) and maternal variables, such as total length (TL) and age, relationships that could indicate a possible effect of female size on egg quality.

Although different aspects of reproductive biology of Argentine Hake have been studied in recent years (Macchi et al., 2004, 2005, 2006, 2007), information about the nutritional condition of spawning females in relation to reproductive potential is scarce. This information is essential for understanding the strategy of energy allocation during reproduction and for estimating whether variations in size composition and feeding condition of spawning females could affect egg quality and, therefore, larval survival. Such information could improve the understanding of the recruitment variations that have been observed in the Argentine Hake fishing stocks.

The objective of this study was to determine which maternal features-length, weight, age, HSI, and condition-were correlated with which measures of egg quality and quantity-DW, oil globule size, and fecundity-in Argentine Hake from Patagonian waters. We also examined stomach fullness as a function of fish length to establish the relationship between feeding activity and the size of spawning females.

\section{Materials and methods}

\section{Sample collection}

Samples of Argentine Hake were obtained from bottom trawls during 2 research surveys carried out in the north Patagonian area during January 2010 and 2011 by the Instituto Nacional de Investigación y Desarrollo Pesquero (INIDEP) (Fig. 1). Argentine Hake specimens were captured at depths between 50 and $110 \mathrm{~m}$ through employment of a bottom trawl with a mouth width of about $20 \mathrm{~m}$, a height of about $4 \mathrm{~m}$, and with a $20-\mathrm{mm}$ mesh size at the inner lining of the codend.

For histological analysis of ovaries, 192 mature females near spawning condition (with hydrated oocytes after germinal vesicle breakdown) were sampled; ovaries were removed and preserved (fixed) in 10\% neutrally buffered formalin. From each specimen, the following measurements were recorded: TL in centimeters and total weight (TW), gutted weight (GW), and liver weight $(\mathrm{LW})$ in grams. In addition, the sagittae otoliths were collected for age determination. Ages were obtained through the use of the methods of Renzi and Pérez (1992).

\section{Female condition and fecundity estimation}

Because fish weight may be greatly influenced by the stomach content and fullness of the gut, GW was used to estimate the condition of Argentine Hake females. 


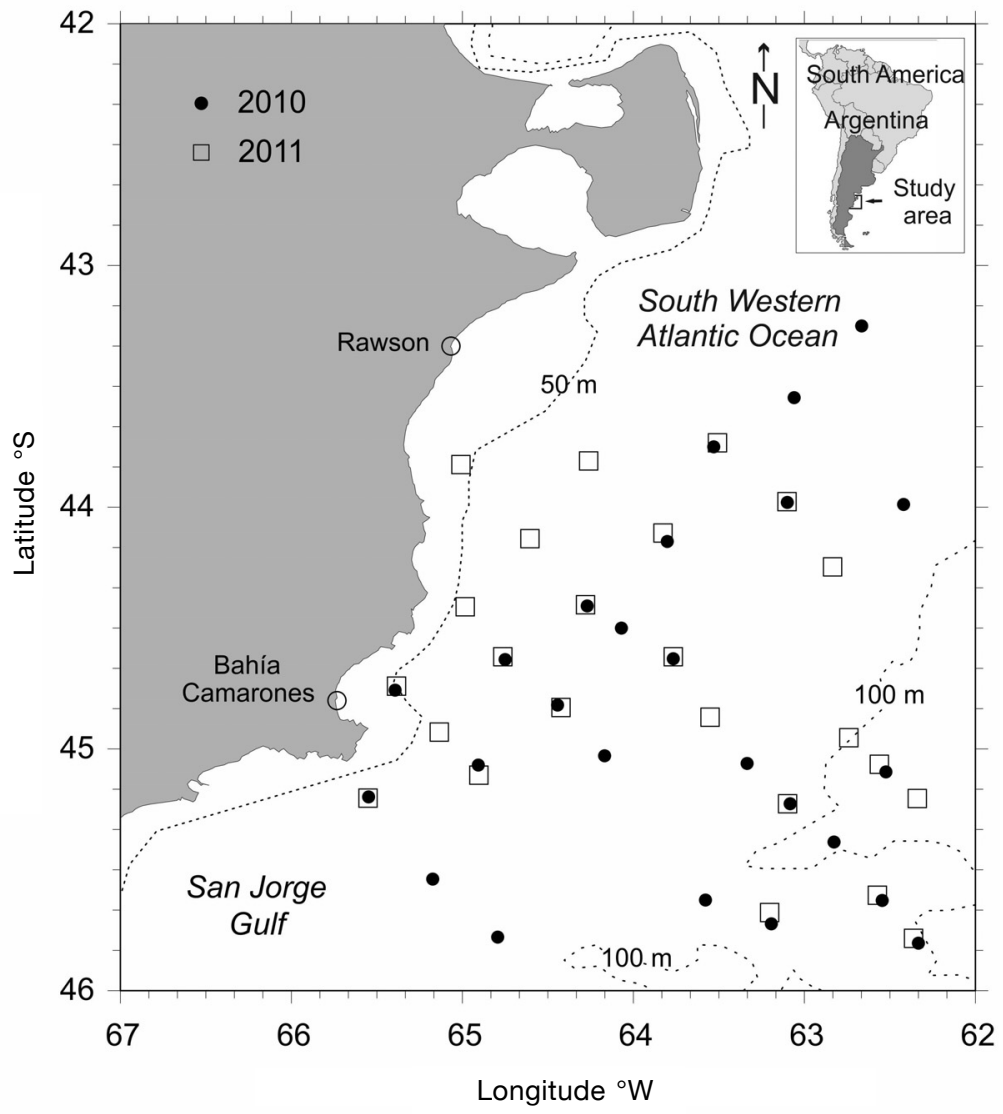

Figure 1

Map of locations where samples of Argentine Hake (Merluccius hubbsi) were collected during the peak spawning season (January) of 2010 (black dots) and 2011 (squares) in waters off the province of Chubut in Argentina to examine maternal effects on the fecundity and egg quality.

Nutritional status was determined by means of 2 indices:

1) the relative condition factor $(\mathrm{Kn})$, expressed as a proportion between the observed GW and the GW determined by the relationship of TL versus GW, described by the following equation:

$$
G W=0.0148 \times T L^{2.7634}
$$

(coefficient of determination $\left[r^{2}\right]=0.98, n=181, P<0.01$ )

2 ) the HSI, which provides an indication of the status of energy reserves in the liver, defined by the following equation:

$$
H S I=(L W / G W) * 100 .
$$

Ovaries collected were weighed to the nearest 0.1 $\mathrm{g}$ after fixation, and a portion of each sample (about $2.0 \mathrm{~g}$ ) was removed from each gonad, dehydrated in ethanol, cleared in xylol, and embedded in paraffin. Sections of ovaries that were $5 \mu \mathrm{m}$ thick were mount- ed and stained with Harris's hematoxylin followed by eosin counterstain. Histological diagnosis was used to discard ovaries with evidence of recent spawning.

Batch fecundity (BF), or the number of oocytes released per spawning, and relative fecundity (RF), or the number of hydrated oocytes per gram of body weight, were estimated with the hydrated oocyte method on fixed ovarian samples (Hunter et al., 1985). Only ovaries without evidence of recent spawning (no postovulatory follicles) were selected (102 ovaries from samples collected in 2010 and 79 ovaries from samples collected in 2011). Three pieces of ovary, approximately $0.1-0.2$ $\mathrm{g}$ each, were removed from the anterior, middle, and posterior parts of one gonad and weighed to the nearest $0.1 \mathrm{mg}$, and hydrated oocytes were counted. Batch fecundity for each female was the product of the mean number of hydrated oocytes per unit of weight and the total weight of the ovaries. Relative fecundity was determined as the batch fecundity divided by female weight (without ovary). 
The relationships of BF to TL obtained in 2010 and 2011 were compared on the basis of overlapping length ranges of the females $(32-83 \mathrm{~cm} \mathrm{TL})$ with analysis of covariance on the log-transformed data (Draper and Smith, 1981). After comparison, the relationships of $\mathrm{BF}$ and RF to TL, gutted weight, age, HSI, and Kn obtained from samples and data collected in both years were described through the use of simple regression analysis.

\section{Egg quality}

A sample of 100 hydrated oocytes was removed from one ovary of each female selected for estimation of fecundity, rinsed in distilled water to remove formaldehyde remnants, dried for $24 \mathrm{~h}$ at $60^{\circ} \mathrm{C}$, and weighed to the nearest $0.1 \mathrm{mg}$. The DW of each of these samples was considered an index of egg quality for the spawning females of Argentine Hake collected during the 2 research cruises because, in general, dry mass is associated with the quantity of yolk reserves stored in oocytes (Macchi et al., 2006; Mehault et al., 2010). The relationships between DW and the different morphophysiological variables (TL, GW, age, HSI, and $\mathrm{Kn}$ ), on the basis of length, weight, or organ-body weight ratios, were evaluated with simple regression analysis as were the fecundity data. Moreover, the relationships between DW and the number of oocytes spawned by batch (BF) and by unit of female weight (RF) were analyzed.

To determine the effect of each maternal attribute on fecundity and egg quality and to establish which of these predictor variables had more influence on the number and quality of the oocytes, multiple regression analyses of $\mathrm{BF}$ and $\mathrm{DW}$ in relation to morphophysiological variables were carried out with the forward stepwise method. In the case of the regression model for BF, the data showed heteroscedasticity and were log-transformed. Colinearity between variables was analyzed to include in the model only those variables that were uncorrelated. All statistical analyses were conducted with $\mathrm{R}$ software ( $\mathrm{R}$ Development Core Team, 2010).

Another variable possibly associated with egg quality is the size of the oil droplet in mature eggs, because it functions as an energy source for larvae (Wiegand, 1996; Nocillado et al., 2000; Rodgveller et al., 2012). For this reason, the diameters of oil droplets in hydrated oocytes were measured in samples of Argentine Hake females collected in January 2011. Samples collected in 2010 were not used, because hydrated oocytes from this year were in bad condition as a consequence of long-term preservation in formalin solution. To analyze possible differences between old and young females, 2 length groups were considered for this analysis: individuals $<40 \mathrm{~cm}$ TL $(n=12)$ and $>70 \mathrm{~cm}$ TL $(n=17)$. Most adult female Argentine Hake $<40 \mathrm{~cm}$ TL are $2-3$ years old and considered first-time spawners for the Patagonian stock of this species (Otero et al., 1986). First-time spawners are thought to produce eggs of lower quality than the eggs of older females, as Trippel (1998) found for Atlantic Cod (Gadus morhua). Hydrated oocytes from each of the 2 length groups of females $(n=641$ and 1000 oocytes) were sampled and the diameters of the oil droplets were measured to the nearest 0.01 $\mu \mathrm{m}$ with a Carl Zeiss ${ }^{3}$ stereomicroscope equipped with AxioVision 4.6 software (Carl Zeiss Microscopy, Jena, Germany). The mean diameters obtained for each size group were compared with a t-test.

Because the size of hydrated oocytes in the ovaries may be influenced by the degree of hydration, we used spawned eggs to analyze the relationship between egg diameter and size of the oil droplet. Therefore, egg diameters and sizes of oil droplets were measured from Argentine Hake eggs collected in plankton samples, from oblique tows conducted with a bongo net (mesh sizes: 300 and $500 \mu \mathrm{m}$ ) in the research survey of January 2010. Samples were fixed in 5\% formalin, and later Argentine Hake eggs in early developmental stages were sorted and rinsed in distilled water. Argentine Hake eggs were identified according to Ehrlich (1998). Egg diameter and size of the oil droplet $(n=102)$ were measured to the nearest $0.01 \mu \mathrm{m}$, as was done for hydrated oocytes, and the relationship between them was evaluated with simple regression analysis.

\section{Feeding activity during spawning}

Stomach fullness of Argentine Hake females during spawning was analyzed to find a possible relationship between feeding activity and the size of spawners. Information on stomach content obtained from all adult females sampled in the reproductive area during the 2 research cruises in January 2010 and $2011(n=2091)$ was considered in this study. Individuals with everted stomachs as a consequence of pressure changes during capture were not used in this analysis. A gross scale of 4 stages was employed to classify the degree of stomach fullness: $0=$ empty, $1=$ few contents ( $<25 \%$ full), $2=$ moderate contents $(25-75 \%$ full $)$ and $3=$ full stomach (Prenski and Angelescu ${ }^{4}$ ). The frequency distribution of each stomach stage by length class was considered in this analysis, but only stage 0 was employed to determine differences in feeding activity. The relationship between the proportion of empty stomachs and female size was described with simple regression analysis.

\footnotetext{
${ }^{3}$ Mention of trade names or commercial companies is for identification purposes only and does not imply endorsement by the National Marine Fisheries Service, NOAA.

${ }^{4}$ Prenski, L. B., and V. Angelescu. 1993. Ecología trófica de la merluza común (Merluccius hubbsi) del Mar Argentino. Parte 3. Consumo anual de alimento a nivel poblacional y su relación con la explotación de las pesquerías multiespecíficas. INIDEP Documento Científico No. 1, 118 p. [Available from INIDEP, Paseo Victoria Ocampo Nro. 1, B7602HSA Mar del Plata, Argentina.]
} 


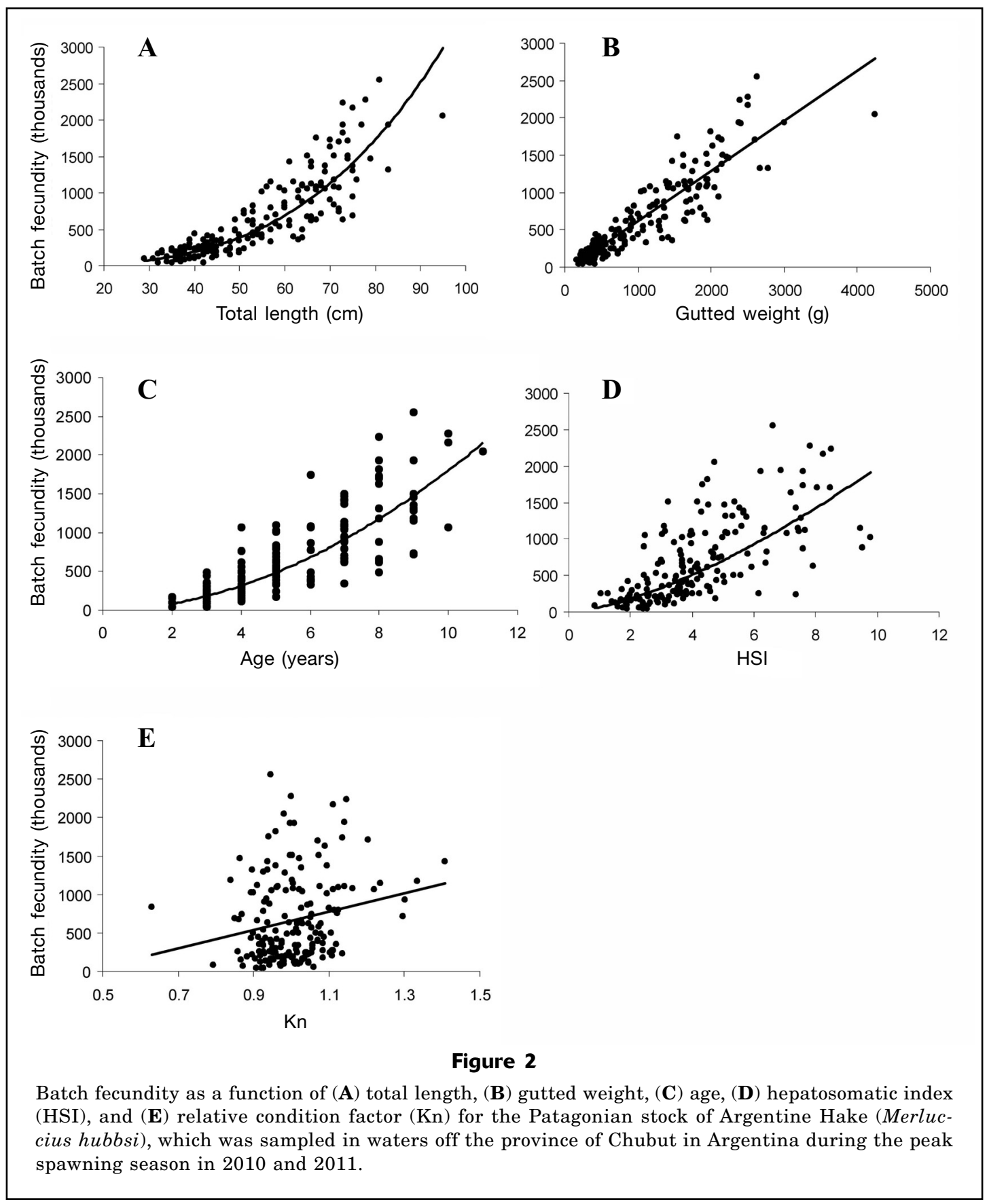

\section{Results}

\section{Female condition and fecundity estimation}

Batch fecundity estimates obtained for Argentine Hake females collected during January 2010 and 2011 ranged between 40,500 hydrated oocytes (29 cm TL) and 2,550,000 hydrated oocytes (95 cm TL). The analysis of covariance applied to compare the coefficients of the relationship of $\mathrm{BF}$ to TL obtained for each year did not show statistical differences $(P>0.01)$; therefore, data from 2010 and 2011 were pooled to estimate all the regression analyses. The relationship between $\mathrm{BF}$ and TL was curvilinear, fitting better to a power model (Fig. 2A, Table 1). The relationship of BF to GW was linear, and, in the case of $\mathrm{BF}$ to age, a power model was fitted (Figs. 2B and C, Table 1).

A positive power relationship was observed between BF and the HSI (Fig. 2D, Table 1). In the case of $\mathrm{BF}$ and $\mathrm{Kn}$, the relationship was linear and significant $(P<0.01)$, but a low $r^{2}$ was obtained (Fig. $2 \mathrm{E}$, Table 1). 


\section{Table 1}

Results of the regression analyses between batch fecundity (BF), relative fecundity (RF), and oocyte dry weight (DW) and the variables of total length (TL), gutted weight (GW), age (A), hepatosomatic index (HSI), and relative condition index (Kn) for female Argentine Hake (Merluccius hubbsi) of the Patagonian stock obtained from bottom trawls during research surveys in January 2010 and 2011. $r^{2}=$ coefficient of determination; $\mathrm{a}$ and $\mathrm{b}=$ parameters of the equation, $n=$ sample size, $P=P$-value of the relationship. The sample size for regressions with age $(n=173)$ was smaller than the sample size for regressions with other variables $(n=181)$ because some otoliths were broken or otherwise unusable for age determination.

\begin{tabular}{rlllcccc}
\hline & & Relationship & $r^{2}$ & $\mathrm{a}$ & $\mathrm{b}$ & $n$ & $P$ \\
\hline & TL & Power & 0.75 & 10.07 & 2.74 & 181 & $<0.01$ \\
$\mathrm{BF}$ & GW & Linear & 0.81 & -64235.60 & 675.48 & 181 & $<0.01$ \\
& A & Power & 0.68 & 38103.41 & 1.67 & 173 & $<0.01$ \\
& HSI & Power & 0.47 & 126319.30 & 1.17 & 181 & $<0.01$ \\
& Kn & Linear & 0.04 & -528543.19 & 1183337.78 & 181 & $<0.01$ \\
& & & & & & \\
& TL & Linear & 0.03 & 396.99 & 2.37 & 181 & $>0.01$ \\
RF & GW & Linear & 0.04 & 471.76 & 0.05 & 181 & $<0.01$ \\
& A & Linear & 0.03 & 448.49 & 15.12 & 173 & $>0.01$ \\
& HSI & Linear & 0.11 & 388.49 & 33.56 & 181 & $<0.01$ \\
& Kn & Linear & 0.07 & 21.68 & 500.84 & 181 & $<0.01$ \\
& TL & Logarithmic & 0.18 & & & & \\
& GW & Logarithmic & 0.17 & 1.62 & 0.0001 & 181 & $<0.01$ \\
DW & Logarithmic & 0.14 & 2.31 & 0.20 & 181 & $<0.01$ \\
& HSI & Linear & 0.18 & 2.49 & 0.34 & 173 & $<0.01$ \\
& Kn & Linear & 0.05 & 2.01 & 0.08 & 181 & $<0.01$ \\
& & & & 0.82 & 181 & $<0.01$ \\
\hline
\end{tabular}

Relative fecundity ranged from 85 to 1040 hydrated oocytes $\mathrm{g}^{-1}$ (female weighed without ovaries), with a mean value of 526 hydrated oocytes $\mathrm{g}^{-1}$ (standard error [SE] 183). Positive linear significant relationships $(P<0.01)$ between $\mathrm{RF}$ and the morphophysiological variables of GW, HSI, and Kn were observed, but $r^{2}$ values were low for all variables, explaining in some cases $3 \%$ or $4 \%$ of the variance (Fig. 3, Table 1). The strongest correlation, with an $r^{2}$ of 0.11 , was obtained with the relationship of RF to the HSI (Table 1).

In the multiple regression analysis of the influence of maternal characteristics on $\mathrm{BF}, 87 \%$ of the variability in BF was explained by GW, DW, and the HSI and described by the following equation:

$$
\begin{gathered}
B F=5.08+0.96 \operatorname{Ln} G W+1.08 \operatorname{Ln} D W \\
+0.27 \operatorname{Ln} H S I \\
\quad\left(r^{2}=0.87, n=178,[P<0.01]\right)
\end{gathered}
$$

Most of this variability was explained exclusively by $\mathrm{GW}(95 \%)$. The forward stepwise method gave evidence that inclusion of other variables did not improve $\mathrm{BF}$ predictions significantly.

\section{Egg quality}

For 100 hydrated oocytes, DW estimated from Argentine Hake females collected during the spawning peak in January 2010 and 2011 ranged from 1.8 to $3.95 \mathrm{mg}$, and had a mean value of $2.83 \mathrm{mg}$ (SE 0.36). There were significant positive relationships between DW and all morphophysiological variables considered during this study: TL, GW, age, HSI, and Kn (Fig. 4, Table $1)$. Moreover, positive significant relationships $(P<0.01)$ also were obtained between DW and fecundity ( $\mathrm{BF}$ and $\mathrm{RF})$, described by the following equations:

$$
\begin{gathered}
D W=2.62+0.0003 B F . \\
\quad\left(r^{2}=0.25, n=181\right) \\
\quad\left(r^{2}=0.16, n=181\right)
\end{gathered}
$$

In general, $r^{2}$ values were low for all relationships estimated and $\mathrm{BF}$ was the variable best correlated with DW, although it is possible that size may have some influence on this relationship. Regardless, RF, which was uncorrelated with TL, also showed a significant positive relationship to DW.

In the multiple regression analysis carried out with DW as the dependent variable and morphophysiological variables, only the HSI and GW were included because the other variables did not improve DW predictions significantly. This model explained $20 \%$ of the total variability, and $90 \%$ of this percentage was contributed by the HSI: 

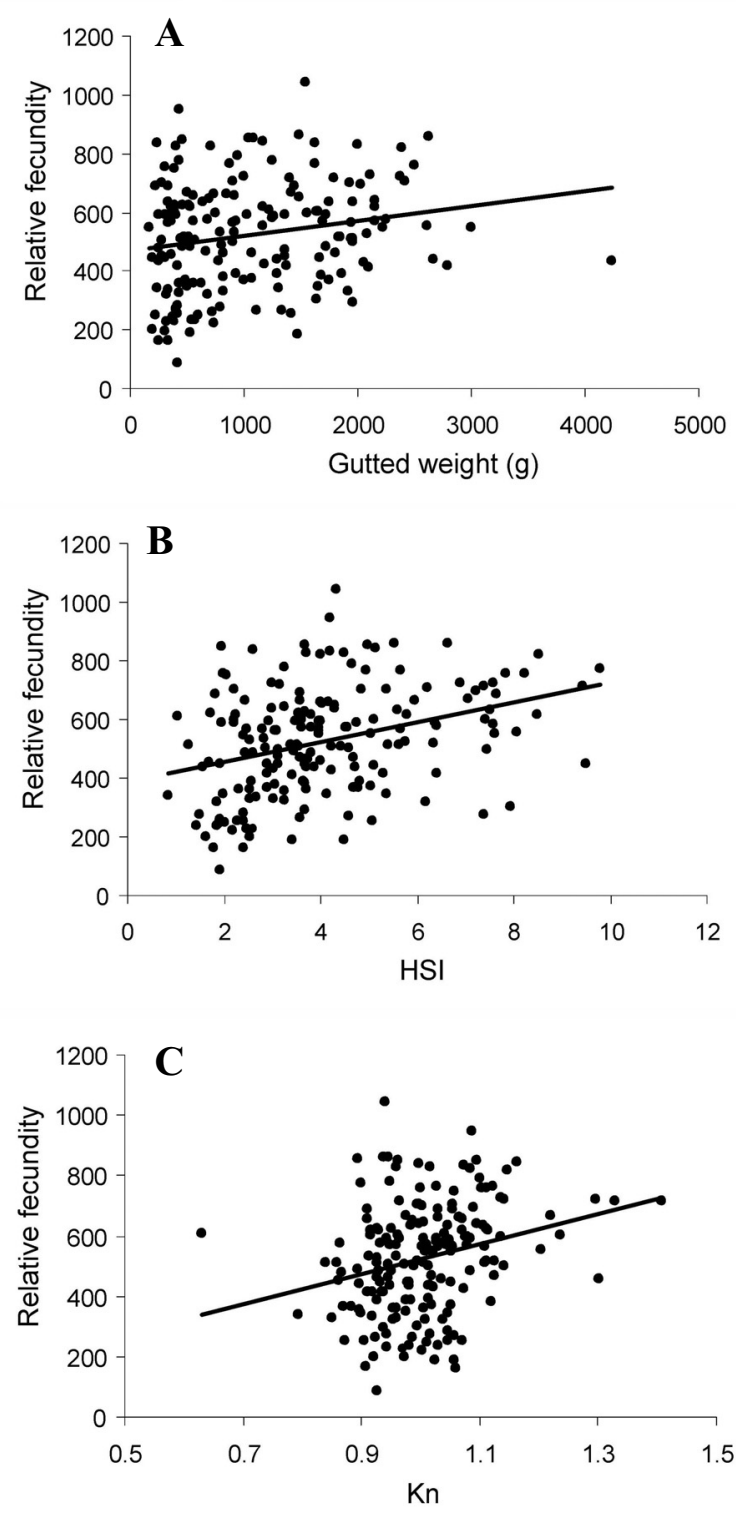

Figure 3

Relative fecundity as a function of (A) gutted weight, (B) hepatosomatic index (HSI), and (C) relative condition factor $(\mathrm{Kn})$ for the Patagonian stock of Argentine Hake (Merluccius hubbsi), which was sampled in waters off the province of Chubut in Argentina during the peak spawning season in 2010 and 2011.

$$
D W=2.49+0.061 H S I+0.00009 G W
$$

$$
\left(r^{2}=0.20, n=178,[P<0.03]\right)
$$

The mean diameters of the oil droplets in hydrated oocytes that were estimated for young $(<40 \mathrm{~cm}$ TL) and old ( $>70 \mathrm{~cm}$ TL) Argentine Hake females were 265.82 $\mu \mathrm{m}$ (SE 20.33) and 275.71 $\mu \mathrm{m}$ (SE 1.49), respectively. Comparison of this variable between both length groups showed highly significant differences $(P<0.001)$, indicating more lipid accumulated in eggs from larger females than in eggs from first-time spawners.

The regression analysis between the sizes of the oil droplets (OD) and egg diameters (ED) of Argentine Hake eggs collected during plankton sampling showed a significant positive relationship $(P<0.01)$, described by the following equation:

$$
O D=0.4168 E D-146.46 .
$$

$$
\left(r^{2}=0.34, n=102\right)
$$

This result corroborates the notion that larger eggs of Argentine Hake have more lipid reserves for larval growth and, therefore, have a higher probability that they will produce larger larvae.

\section{Feeding activity during spawning}

The regression analysis between the proportion of empty stomachs (PE) and TL for data obtained in January 2010 and 2011 showed a significant negative logarithmic relationship $(P<0.01)$, indicating that intensity of feeding during spawning increases with female size. This tendency was more evident in Argentine Hake females $<55 \mathrm{~cm}$ TL because individuals of this species in larger length classes showed high variability in feeding activity (Fig. 5). This relationship was described by the following equation:

$$
\begin{array}{r}
P E=1.6824-0.2937 \operatorname{Ln} T L . \\
\left(r^{2}=0.39, n=45\right)
\end{array}
$$

\section{Discussion}

Batch fecundity values for the Patagonian stock of Argentine Hake, estimated with samples collected in January 2010 and 2011, did not differ statistically and showed a positive relationship with size, weight, and age of the spawning females. The range of fecundity data $(40,500-2,550,000$ hydrated oocytes) was similar to estimated values from previous studies of Argentine Hake during the same month in other years (Macchi et al., 2004), but the range was much higher than values obtained for other species of Merluccius: Peruvian Hake (M. gayi peruanus) (see Canal, 1989), New Zealand Hake (M. australis) (see Balbontín and Bravo, 1993), European Hake (M. merluccius) (see Murua et al., 2006; Recasens et al., 2008; El Habouz et al., 2011), Cape Hake (M. capensis), and Deepwater Hake (M. paradoxus) (see Osborne et al., 1999). Batch fecundity was influenced also by female condition, expressed mainly by liver weight, as was evident from the positive relationship between the number of eggs produced by batch and the HSI. In addition, relative fecundity, a variable that did not show a significant relationship with female size in Argentine Hake (Macchi et al., 2004), also was influenced positively by the HSI. 

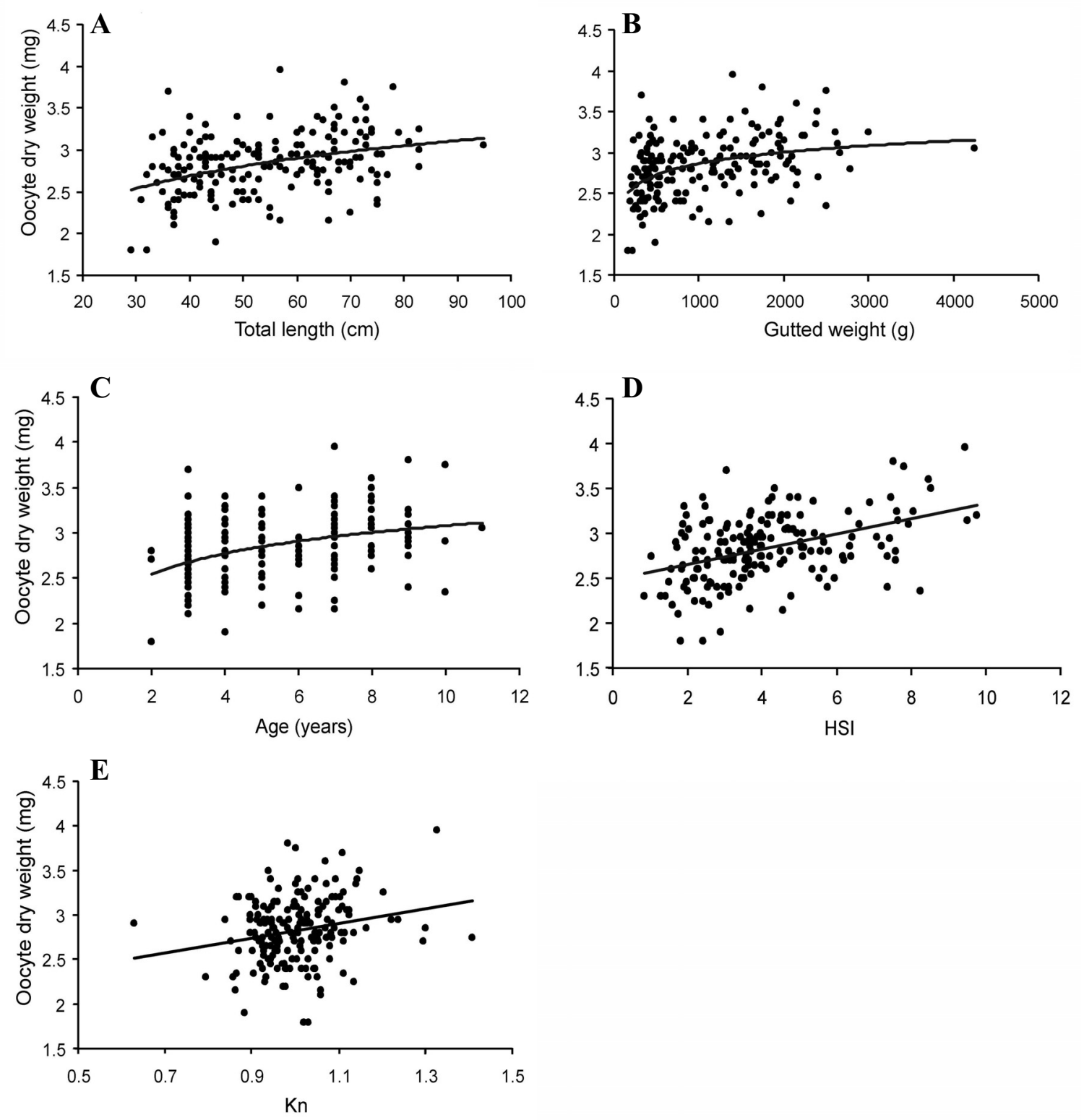

Figure 4

Dry weight of 100 hydrated oocytes as a function of (A) total length, (B) gutted weight, (C) age, (D) hepatosomatic index (HSI), and (E) relative condition factor (Kn) for the Patagonian stock of Argentine Hake (Merluccius hubbsi), which was sampled in waters off the province of Chubut in Argentina during the peak spawning season in 2010 and 2011.

The hepatosomatic index was the maternal condition measure that best correlated with fecundity in Argentine Hake in this study. Different authors have reported that the liver is the main deposit of lipids for gadoids and have considered this organ as the main source of energy for reproduction (Lambert and Dutil, 1997; Alonso-Fernández, 2011). In addition, certain egg constituents, such as yolk proteins and egg coat substances, are synthesized in the liver (Brooks et al.,
1997). It has been suggested that lipids play a key role during the early life history of many species (Nocillado et al., 2000), serving as structural components of membranes and providing physical protection of organs, buoyancy, or nutrients for embryos (Wiegand, 1996). Lipids of oocytes are stored mainly as lipoproteins, which are the major components of oocyte yolk, or as oil droplets (Wiegand, 1996). In Atlantic Cod, it has been suggested that the HSI is a good index of repro- 


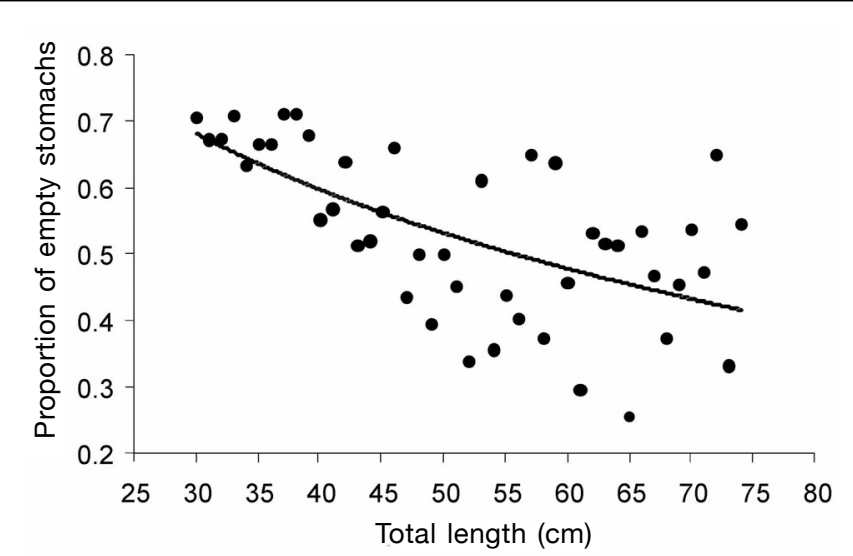

Figure 5

Relationship between proportion of females with empty stomachs and female size obtained for the Patagonian stock of Argentine Hake (Merluccius hubbsi), which was sampled in waters off the province of Chubut in Argentina during the peak spawning season in January 2010 and 2011.

ductive potential because of the role that lipids serve in reserving energy (Marshall et al., 1999). Supporting this idea, Leonarduzzi et al. (2012) analyzed the proximal composition of different tissues in Argentine Hake females and showed that the best morphological index for the somatic condition in Argentine Hake is the HSI-a finding that agrees with results obtained for other fish species (Alonso-Fernández, 2011). Therefore, it is reasonable to assume that reproductive potential of Argentine Hake may be affected by the liver condition of spawning females.

Positive relationships between DW and the variables of TL, GW, and age were observed for Argentine Hake-results that coincide with previous studies of this species (Macchi et al., 2006), and for European Hake (Mehault et al., 2010). Moreover, the positive relationship between DW and fecundity indicates that larger females of Argentine Hake invest energy in both the quantity and quality of the oocytes that they produce. The increases observed in oocyte mass with female size for Argentine Hake agrees with the hypothesis of a maternal effect on the spawning quality of this species. Argentine Hake also showed a positive relationship between DW and female condition, expressed by the HSI. This result supports the idea that the size and composition of oocytes depend on the maternal nutritional state and are particularly associated with liver weight (Marteinsdottir and Begg, 2002).

The difference observed between the size of the oil droplets in hydrated oocytes of first-time spawners $(<40$ $\mathrm{cm}$ TL) and old females ( $>70 \mathrm{~cm}$ TL) also reflected the maternal contribution to reproductive success. Oocytes of old individuals were characterized by oil globules that were larger than the oil globules of young spawners, indicating that more lipids were stored in the eggs of larger females. In other fish species that have been studied (e.g., Sebastes spp.), older females produced eggs with larger oil globules, which result in larvae with better chance of survival (Berkeley et al., 2004; Sogard et al., 2008). Similar conclusions indicating that fatty acids are essential for egg composition and reproductive success were drawn with species maintained in captivity and fed with different concentrations of lipids (Watanabe et al., 1984; Fernández-Palacios et al., 1995; Sewall and Rodgveller, 2009). Furthermore, the positive relationship observed in Argentine Hake in this study between the sizes of eggs from plankton samples and diameters of their oil droplets indicates that larger eggs contain a higher amount of lipids than do smaller eggs, supporting the idea that bigger oocytes are of better quality.

The decrease in frequency of empty stomachs with the size of the Argentine Hake females is evidence that feeding activity is higher in larger individuals. In addition, this result supports the hypothesis of continuous feeding during breeding season for other hake species (Dominguez-Petit and Saborido-Rey, 2010). The relationship between the percentage of individuals with empty stomachs and TL was more evident in females $<55 \mathrm{~cm}$ TL; at this size range, the slope of the equation was more pronounced. This break in the regression model is similar to the break previously found for the relationship of oocyte weight to female size in Argentine Hake (Macchi et al., 2006). Those authors reported that differences between egg mass and female size can be observed mainly in young spawners $(<55 \mathrm{~cm}$ TL) because, in females $>55$ $\mathrm{cm}$ TL, the slope of the model decreased, as a consequence of the high variability in oocyte weight.

Female condition and the quality of eggs produced by Argentine Hake may be associated with the feeding range of this species. It is possible that larger individuals would be capable of swimming longer distances as they search for food in deeper waters, where it is common to find great concentrations of squid (Ilex argentinus) in the austral summer. This squid species is considered the most important prey for larger individuals of Argentine Hake in the Patagonian area (Angelescu and Prenski, 1987). A recent study described an offshore spawning group of Argentine Hake in Patagonian waters in January that was characterized by a high proportion of females $>55 \mathrm{~cm}$ TL and older than 5 years (Macchi et al., 2010). The selection of squid for food by larger females may be advantageous for spawning, if the high concentration of fatty acids detected in this mollusk is taken into account (Watanabe et al., 1984). Therefore, studies on Argentine Hake diet and the effect of diet composition on egg quality are needed. In particular, further information is required about lipid, fatty acids, proteins, and ascorbic acid content, all rel- 
evant components that affect egg and embryo survival (Brooks et al., 1997; Sewall and Rodgveller, 2009).

\section{Conclusions}

This study provides further evidence of maternal influence on the reproductive potential and spawning quality of the Patagonian stock of Argentine Hake. Within the analyzed size range (29-95 cm TL), larger females were characterized not only by higher fecundities but also by heavier eggs with larger oil droplets. Larger individuals were in better condition than smaller ones, as shown by higher HSI values, supporting the assumption that this index is a good predictor of reproductive potential. Moreover, feeding activity during the spawning peak in January was higher for larger females than for smaller and younger individuals, indicating that Argentine Hake may incorporate energy during the reproductive season. This strategy of energy allocation is typical of an income breeder and is similar to the strategy suggested for the European Hake by Dominguez-Petit and Saborido-Rey (2010). However, because Argentine Hake may be an opportunistic feeder during reproduction, it may be advantageous for spawning females to feed on higher quality food, such as squid, found offshore. This benefit may be restricted to larger individuals because they are more likely than smaller females to have the ability to find food offshore.

\section{Acknowledgments}

We wish to thank M. Estrada and H. Brachetta for preparation of the histological sections. Special thanks to M. Iorio and C. Dato for their help during sample collection and the technical staff of the Hake Assessment Group of the INIDEP for age determination. We also would like to thank the anonymous reviewers for making suggestions to improve this manuscript. This work was supported by the INIDEP and the CONICET (PIP 112200801 00815). This is INIDEP contribution no. 1822.

\section{Literature cited}

Alonso-Fernández, A.

2011. Bioenergetics approach to fish reproductive potential: case of Trisopterus luscus (Teleostei) on the Galician Shelf (NW Iberian Peninsula). Ph.D. diss., 266 p. Univ. Vigo, Vigo, Spain.

Álvarez-Colombo, G., C. Dato, G. J. Macchi, E. Palma, L. Machinandiarena, H. E. Christiansen, P. Betti, P. Martos, F. Castro-Machado, D. Brown, M. Ehrlich, H. Mianzan, and M. Acha.

2011. Distribution and behavior of Argentine hake larvae: evidences of a biophysical mechanism for self-recruitment at the North Patagonian shelf waters. Cienc. Mar 37:633-657.
Angelescu, V., and L. B. Prenski.

1987. Ecología trófica de la merluza común del mar argentino (Merluccidae, Merluccius hubbsi). Parte 2. Dinámica de la alimentación analizada sobre la base de las condiciones ambientales, la estructura y las evaluaciones de los efectivos en su área de distribución. Contrib. Inst. Nac. Invest. Desarr. Pesq. 561:1-205.

Aristizabal, E. O.

2007. Energy investment in the annual reproductive cycle of red porgy (Pagrus pagrus). Mar. Biol. 152:713-724.

Aubone, A., S. Bezzi, R. Castrucci, C. Dato, P. Ibañez, G. Irusta, M. Pérez, M. Renzi, B. Santos, N. Scarlato, M. Simonazzi, L. Tringali, and F. Villarino.

2000. Merluza (Merluccius hubbsi). In Síntesis del estado de las pesquerías marítimas argentinas y de la Cuenca del Plata. Años 1997-1998, con una actualización de 1999 (S. Bezzi, R. Akselman, and E. Boschi, eds.), p. 29-40. Publicaciones Especiales INIDEP (Instituto Nacional de Investigación y Desarrollo Pesquero), Mar del Plata, Argentina.

Balbontín, F., and R. Bravo.

1993. Fecundidad, talla de la primera madurez sexual y datos biométricos en la merluza del sur Merluccius australis. Rev. Biol. Mar. 28:111-132.

Berkeley S. A, C. Chapman, and S. M. Sogard.

2004. Maternal age as a determinant of larval growth and survival in a marine fish, Sebastes melanops. Ecology 85:1258-1264.

Bromage, N., M. Bruce, N. Basavaraja, K. Rana, R. Shields, C. Young, J. Dye, P. Smith, M. Gillespie, and J. Gamble.

1994. Egg quality determinants in finfish: the role of overripening with special reference to the timing of stripping in the Atlantic halibut Hippoglossus hippoglossus. J. World Aquacult. Soc. 25:13-21.

Brooks, S., C. R. Tyler, and J. P. Sumpter.

1997. Egg quality in fish: what makes a good egg? Rev. Fish Biol. Fish. 7:387-416.

Canal, R. L.

1989. Evaluación de la capacidad y condición reproductiva de la merluza (Merluccius gayi peruanus). Bol. Inst. Mar Peru 13:40-70.

Domínguez-Petit, R., and F. Saborido-Rey.

2010. New bioenergetic perspective of European hake (Merluccius merluccius L.) reproductive ecology. Fish. Res. 104:83-88.

Domínguez-Petit, R., F. Saborido-Rey, and I. Medina.

2010. Changes of proximate composition, energy storage and condition of European hake (Merluccius merluccius L. 1758) through the spawning season. Fish. Res. 104:73-82.

Draper, N. R., and H. Smith.

1981. Applied regression analysis, 2nd ed., 709 p. Wiley, New York.

El Habouz, H., L. Recasens, S. Kifani, A. Moukrim, A. Bouhaimi, and S. El Ayoubi.

2011. Maturity and batch fecundity of the European hake (Merluccius merluccius, Linnaeus, 1758) in the eastern central Atlantic. Sci. Mar. 75:447-454.

Ehrlich, M. D.

1998. Los primeros estadios de vida de la merluza Merluccius hubbsi Marini 1933, como aporte al conocimiento de su reclutamiento y estructura poblacional. Ph.D. diss., 318 p. Facultad de Ciencias Exactas y Naturales, Univ. Buenos Aires, Buenos Aires, Argentina. 
Fernández-Palacios, H., M. S. Izquierdo, L. Robaina, A. Valencia, M. Salhi, and J. M. Vergara.

1995. Effect of n-3 HUFA level in broodstock diets on egg quality of gilthead seabream (Sparus aurata L.). Aquaculture 132:325-337.

Hinckley, S.

1990. Variation of egg size of walleye pollack Theragra chalcogramma with a preliminary examination of the effect of egg size on larval size. Fish. Bull. 88:471-483.

Hunter, J. R., N. C. H. Lo, and R. J. H. Leong.

1985. Batch fecundity in multiple spawning fishes. In An egg production method for estimating spawning biomass of pelagic fish: application to the northern anchovy, Engraulis mordax (R. Lasker, ed.), p. 67-77. NOAA Tech. Rep. NMFS 36.

Kjesbu, O. S., P. Solemdal, P. Bratlan, and M. Fonn.

1996. Variation in annual egg production in individual captive Atlantic cod (Gadus morhua). Can. J. Fish. Aquat. Sci. 53:610-620.

Lambert, Y., and J. D. Dutil.

1997. Can simple condition indices be used to monitor and quantify seasonal changes in the energy reserves of Atlantic cod (Gadus morhua)? Can. J. Fish. Aquat. Sci. 54:104-112.

Lambert Y., N. A. Yagarina, G. Kraus, G. Marteinsdottir, and P. J. Wright.

2003. Using environmental and biological indices as proxies for egg and larval production of marine fish. J. Northwest Atl. Fish. Sci. 33:115-159.

Landaeta, M. F., and L. R. Castro.

2012. Seasonal and annual variation in Chilean hake Merluccius gayi spawning locations and egg size off Central Chile. Prog. Oceanogr. 92-95:166-177.

Leonarduzzi, E. , A. Massa, and E. Manca.

2012. Variación de la composición bioquímica en hembras de merluza común (Merluccius hubbsi) durante el ciclo reproductivo. Rev. Invest. Desarr. Pesq. 21:5-19.

Macchi, G. J., P. Martos, R. Reta, and C. Dato. 2010. Offshore spawning of the Argentine hake (Merluccius hubbsi) Patagonian stock. PanamJAS 5:22-35.

Macchi, G. J., M. Pájaro, and C. Dato.

2007. Spatial variations of the Argentine hake (Merluccius hubbsi) spawning shoals in the Patagonian area during a reproductive season. Rev. Biol. Mar. Oceanog. 42:345-356.

Macchi, G. J., M. Pájaro, and M. Ehrlich.

2004. Seasonal egg production pattern of the Patagonian stock of Argentine hake (Merluccius hubbsi). Fish. Res. 67:25-38

Macchi, G. J., M. Pájaro, and A. Madirolas.

2005. Can a change in the spawning pattern of Argentine hake (Merluccius hubbsi) affect its recruitment? Fish. Bull. 103:445-452.

Macchi, G. J., M. Pájaro, M. I. Militelli, N. Radovani, and L. Rivas.

2006. I nfluence of size, age and maternal condition on the oocyte dry weight of Argentine hake (Merluccius hubbsi). Fish. Res. 80:345-349.

Marshall, T., O. S. Kjesbu, N. A. Yaragina, P. Solemdal, and

O. Ulltang.

1998. Is spawner biomass a sensitive measure of the reproductive and recruitment potential of Northeast Arctic cod? Can. J. Fish. Aquat. Sci. 55:1766-1783.
Marshall, C. T., N. A. Yaragina, Y. Lambert, and O. S. Kjesbu. 1999. Total lipid energy as a proxy for total egg production by fish stocks. Nature 402:288-290.

Marteinsdottir, G., and G. A. Begg.

2002. Essential relationships incorporating the influence of age, size and condition on variables required for estimation of reproductive potential in Atlantic cod Gadus morhua. Mar. Ecol. Prog. Ser. 235:235-256.

Marteinsdottir G., and K. Thorarinsson.

1998. Improving the stock-recruitment relationship in Icelandic cod (Gadus morhua L.) by including age diversity of spawners. Can. J. Fish. Aquat. Sci. 55:1372-1377.

Mehault, S., R. Domínguez-Petit, S. Cerviño, and F. Saborido-Rey.

2010. Total egg production and implications for management of the Southern stock of European hake. Fish. Res. 104:111-122.

Murua, H., P. Lucio, M. Santurtun, and L. Motos.

2006. Seasonal variation in egg production and batch fecundity of European hake Merluccius merluccius (L.) in the Bay of Biscay. J. Fish Biol. 69:1304-1316.

Nissling, A., R. Larsson, L. Vallin, and K. Frohlund. 1998. Assesment of egg and larval viability in cod, Gadus morhua: methods and results from an experimental study. Fish. Res. 38:169-186.

Nocillado, J. N., V. D. Peñaflorida, and I. G. Borlonga.

2000. Measures of egg quality in induced spawns of the Asian sea bass, Lates calcarifer Bloch. Fish Physiol. Biochem. 22:1-9.

Osborne, R. F., Y. C. Melo, M. D. Hofmeyer, and D.W. Japp. 1999. Serial spawning and batch fecundity of Merluccius capensis and M. paradoxus. S. Afr. J. Mar. Sci 21:211-216.

Otero, H. O., M. S. Giangiobe, and M. A. Renzi.

1986. Aspectos de la estructura de población de la merluza (Merluccius hubbsi). II Distribución de tallas y edades. Estadios sexuales. Variaciones estacionales. Publ. Com. Téc. Mix. Fr. Mar. 1(1):147-179.

R Development Core Team.

2010. R: a language and environment for statistical computing. R Foundation for Statistical Computing, Vienna, Austria. [Available from: http://R-project.org, accessed December 2010.]

Recasens, L., V. Chiericone, and P. Belcari.

2008. Spawning pattern and batch fecundity of the European hake (Merluccius merluccius (Linnaeus, 1758)) in the western Mediterranean. Sci. Mar. 72:721-732.

Renzi M. A., and M. A. Pérez.

1992. Un criterio para la determinación de la edad en juveniles de merluza (Merluccius hubbsi) mediante la lectura de otolitos. Frente Maritimo 11(A):15-31.

Rijnsdorp, A. D., and B. Vingerhoed.

1994. The ecological significance of geographical and seasonal differences in egg size in sole Solea solea (L.). Neth. J. Sea Res. 32:255-270.

Rodgveller, C. J., C. R. Lunsford., and J. T. Fujioka.

2012. Effects of maternal age and size on embryonic energy reserves, developmental timing, and fecundity in quillback rockfish (Sebastes malliger). Fish. Bull. 110:35-45.

Sánchez, R. P., G. Navarro, and V. Rozycki. 2012. Estadísticas de la Pesca Marina en la Argen- 
tina. Evolución de los desembarques 1898-2010, 528 p. Ministerio de Agricultura, Ganadería y Pesca de la Nación, Buenos Aires, Argentina.

Sewall F., and C. J. Rodgveller.

2009. Changes in body composition and fatty acid profile during embryogenesis of quillback rockfish (Sebastes maliger). Fish. Bull. 107:207-220.

Sogard, S. M., S. A. Berkeley, and R. Fisher.

2008. Maternal effects in rockfishes Sebastes spp.: a comparison among species. Mar. Ecol. Prog. Ser. $360: 227-236$.
Trippel, E. A.

1998. Egg size and viability and seasonal offspring production of young Atlantic cod. Trans. Am. Fish. Soc. 127:339-359.

Watanabe, T., T. Arakawa, C. Kitajima, and S. Fujita. 1984. Effect of nutritional quality of broodstock diets on reproduction of Red Sea bream. Bull. Jap. Soc. Sci. Fish. 50:495-501.

Wiegand, M. D.

1996. Composition, accumulation and utilization of yolk lipids in teleost fish. Rev. Fish Biol. Fish. 6:259-286. 